\title{
Perlindungan Hukum Bagi Pihak Pembeli Atas Batalnya Akta Jual Beli Yang Dibuat Oleh Notaris
}

\author{
Ida Ayu Gita Srinita ${ }^{1}$,Dewa Nyoman Rai Asmara Putra ${ }^{2}$
}

${ }^{1}$ Magister Kenotariatan Fakultas Hukum Universitas Udayana, Bali, Indonesia, Email: ayugitasrinita@gmail.com

2Fakultas Hukum Universitas Udayana, E-mail: dewar2566@gmail.com

\begin{tabular}{l}
\hline Info Artikel \\
\hline Masuk:13 Juli 2020 \\
Diterima:16 Juli 2020 \\
Terbit: 6 Januari 2021 \\
Keywords: \\
legal protection, land, buy and \\
sell certificate
\end{tabular}

\begin{abstract}
The benefits of land in human life today are very important, because land can be used as a place to live, for gardening, and can be used for investment, for example leasing or transferring property rights to meet their daily needs. The transfer of property rights is carried out by means of a sale and purchase system, the legal basis is Article 26 of the Basic Agrarian Law, al though it does not specifically determine the sale and purchase but describes the transfer or transfer which can be interpreted as a legal event that was deliberately agreed to with the intention of transferring land rights to a debtor who can be said to be a buyer by way of exchange, or by means of a will. The agreement for the transfer of title to land should be put in a written form and must be in accordance with the provisions in which the deed of sale and purchase of land rights must be worked out and legalized by the authorized official, namely PPAT. The certificate made or issued by the PPAT becomes strong evidence in court, because the agreement was made in advance of the PPAT and witnessed by 2 people. The research objective of this journal is to find out how the buyer protects the cancellation of the land sale and purchase deed that was sued by the defendant's stepmother as contained in the Supreme Court Judgment on Reconsideration No. 337 PK / Pdt / 2015. The research in this journal uses empirical research where it starts from a gap between the prevailing norms and the reality of its implementation in society. Then the conclusion of this study which is based on the Supreme Court Reconsideration Decision No.337 PK/Pdt/2015, which states that the seller must return the money and interest, to be used by the buyer to buy the land, and vice versa, the buyer must return the land it has bought from the seller. Before selling the land, the seller should have previously negotiated with all members of his family, so that neither party would suffer losses and sue for legal action, because the buyer is in a disadvantaged position
\end{abstract}

\footnotetext{
Abstrak

Manfaat tanah dalamkehidupan manusia pada zaman sekarang sangatlah penting, karena tanah dapat digunakan sebagai tempat untuk tinggal, untuk berkebun, serta bisa digunakan untuk berinvestasi misalnya dikontrakkan atau dialihkan hak miliknya untuk memenuhi kebutuhan kehidupannya sehari-hari. Pemindahan hak milik dilakukan dengan sistem jual beli, dasar
} 


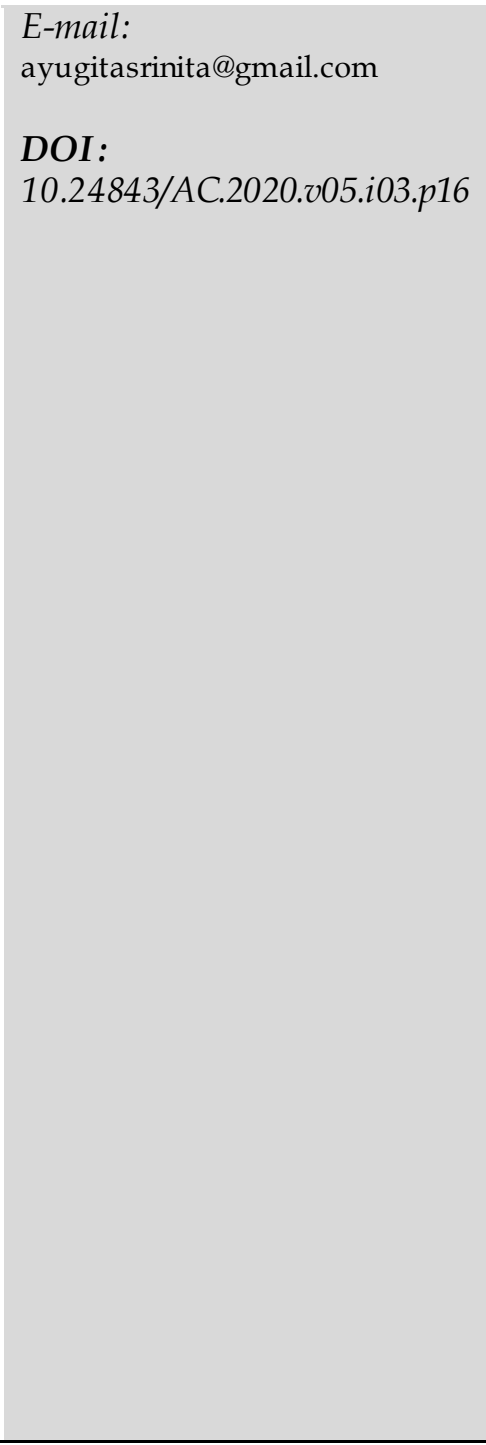

hukumnya ada pada dapat Pasal 26 Undang-Undang Pokok Agraria, walaupun didalamnya tidak secara spesifik menentukan tentang jual beli malainkan menjelaskan tentang peralihan atau mengalihkan yang dapat diartikan sebagai peristiwa hukum yang memang sengaja diperjanjikan dengan maksud memindahkan hak atas tanah kepada debitur yang dapat dikatakan sebagaipembeli dengan cara tukar menukar, maupun dengan hibahwasiat. Kesepakatan perjanjian pemindahan hak milik atas tanah sepatutnya dituangkan kedalam bentuk tertulis wajib selaras dengan ketentuan-ketentuan yang dimana aktajual beli hak atas tanah harus dikerjakan dan dilegalkan oleh Pejabat yang berwenang yaitu PPAT. Sertifikat yang dibuat atau dikeluarkan oleh PPAT menjadi alat bukti kuat dalam persidangan, sebab perjanjian tersebut dibuat dimuka PPAT dan disaksikan oleh 2 orang. Tujuan penelitian jurnal ini yaitu untuk mengetahui bagaimanaperlindungan kepadapembeli atas batalnya akta jual beli tanah yang digugat dengan ibu tiri tergugat seperti yang adadidalam Putusan Peninjauan Kembali Mahkamah Agung No. 337 PK/Pdt/2015. Penelitian dalam jurnal ini menggunakan penelitian empiris dengan mana beranjak dari adanya kesenjangan antara norma yang berlaku dengan realita pelaksanaannya dalam masyarakat. Kemudian kesimpulan dari penelitian ini yang berdasar kepada Putusan Peninjauan Kembali Mahkamah Agung No. 337 PK/Pdt/2015, yang menyatakan bahwa pihak penjual wajib menyerahkan kembali uang beserta bunganya, untuk digunakan pada pihak pembeli untuk membeli tanah tersebut, dan sebaliknya pihak pembeli harus mengembalikan tanah yang telah dibelinya dari pihak penjual. Seharusnya sebelum menjual tanah tersebut, pihak penjual terlebih dahulu merundingkan kepada seluruh anggota keluargnya, supaya tidak ada pihakyang dirugikan dan menuntut kejalur hukum, karena pihak pembeli berada diposisi yang dirugikan.

\section{Pendahuluan}

Tanah adalah karunia yang diciptakan oleh Tuhan yang sangat bermanfaat dalam hidup setiap makhluk hidup. Tanah memiliki banyak fungsi dalam kehidupan makhluk hidup. Pasal 33 Undang-Undang Dasar 1945 yang pada esensinya mengutarakan tentang kemakmuran rakyat bergantung pada kekayaan alam seperti tanah dan air yang kemudian dikelola oleh Negara.

Eksistensi tanah mempunyai makna ganda pada keberlangsungan hidup manusia yaitu social asset dan capital asset. Capital asset memiliki arti tanah dapat tumbuh sebagai objek ekonomi, yang pembangunannya dapat menjadi modal yang dimaknai krusial dan dapat menjadi objek perniagaan, sedangkan social asset memiliki arti suatu sarana untuk mengikat dalam kesatuan social masyrakat dalam menjalani hidup dan kehidupannya. ${ }^{1}$

\footnotetext{
${ }^{1}$ Achmad Rubaie.(2007). Hukum Pengadaan Tanah Untuk Kepentingan Umum. Malang. Bayumedia. h.1
} 
Peraturan yang mengatur tentang tanah yaitu Undang-Undang Nomor 5 Tahun 1960 tentang Peraturan Dasar Pokok-Pokok Agraria yang (selanjutnya disebut UUPA), huruf "a" yang pada intinya menententukan bumi, air, dan ruang angkasa adalah anugerah Tuhan, dengan memiliki tujuan utama yaitu menciptakan kehidupan bermasyarakat yang adil dan makmur. Konsideran menimbang huruf "a" menujukkan landasan filosofis dari pada mengapa diundangkannya UUPA. Undang-Undang Dasar 1945 menjamin hak milik atas tanah yan merupakan bagian dari hak kebendaan.

Dasar hukum perihal hak milik atas tanah dirumuskan pada Pasal 4 ayat (2) UUPA pada intinya menafsirkan hak atas tanah dimaksudkan yaitu memberi hak kepada pihak yang berkepentingan untuk menggunakan tanah, tetapi hanya melingkupi bagian tertentu yang telah diperjanjikan kemudian disebut sebidang tanah. Hak milik atas tanah mencakup dua unsur yaitu hak kebendaan dan hak perseorangan. Ciri hak kebendaan yang absolute yaitu mempunyai masa waktu yang tidak memiliki batas, hak yang mengikuti benda tersebut (droit de suite), dan memeberikan kewenangan kepada pemiliknya untuk dijadikan jaminan, dialihkan, disewakan atau dipergunakan untuk dirinya sendiri. Sedangkan untuk hak perseorangan yang memiliki ciri yang bersifat relative yaitu mempunyai batas waktu dan juga hanya memberikan kewenangan yang terbatas kepada pemiliknya. ${ }^{2}$

Hak milik atas tanah yang telah dirumuskan didalam Pasal 20 ayat (1) UUPA pada intinya menjelaskan:

1. Hak milik merupakan hak didapat dari generasi ke generasi, terkuat dan penuh yang dapat dimiliki oleh orang atas tanah dengan mengingat fungsi sosialnya;

2. Hak milik ini bisa berganti tangan dari satu pembeli ke pembeli lain, dengan transaksi jual beli adalah cara yang bias dilakukan untuk mengalihkan hak milik atas tanah ini dengan transaksi jual beli.

Jual beli dapat menjadi upaya yang digunakan untuk mengalihkan kepemilikan hak milik atas tanah. Undang-Undang Pokok Agraria dalam esensinya belum menentukan secara terperinci mengatur pelaksanaan jual beli hak atas tanah. ${ }^{3}$ Aturan dari Pasal 26 Undang-Undang Pokok Agraria didalamnya menyinggung tentang jual beli tanah. Dalam ketentuan pasal 26 ini tidak menyebutkan secara spesifik tentang jual beli, melainkan mengalihkan atau dialihkan yang dapat diartikan adanya peristiwa hokum yang dengan persetujuan para pihak dilakukan pemindahan atau pengalihan hak atas tanah kepada pihak yang diperjanjikan menggunakan cara hibah dan jual beli. ${ }^{4}$

Perbuatan hukum jual beli hak atas tanah adalah suatu peristiwa hukum yang dapat dikatakan bersifat tunai. Kemudian setelah perbuatan pemindahan hak disepakati maka hak yang dimiliki oleh penjual akan beralih dan berpindah menjadi hak milik atas tanah si pembeli setelah dilakukannya pembicaraan dan salin sepakat yang disetujui oleh para pihak yang terlibat beserta saksi dimuka PPAT. PPAT adalah seseorang yang mempunyai wewenang untuk membuat dan melegalisasi akta berdasar pada aturan perundang-undangan, telah diatur pada ketentuan Pasal 37

\footnotetext{
${ }^{2}$ Badrulzaman, Mariam Darius. (1997). MencariSistem Hukum Benda Nasional, Bandung: Alumni, h. 31

${ }^{3}$ Adrian Sutedi. (2009). Peralihan Hak Atas Tanah dan Pendaftrannya. Jakarta. Sin ar Grafika. H.11

${ }^{4}$ Dananjaya, N. S.(2016). Pembatalan Sertipikat Hak Milik Dan Akibat Hukumnya Terhadap Akta Jual

Beli.Jurnal Bina Mulia Hukum. Volume 1, Nomer 1. h.63
} 
Peraturan Pemerintah Nomor 24 tahun 1997 yang menjelaskan akta peralihan yang dilakukan dengan kesepakatan jual beli kemudian bisa didaftarkan oleh pejabat publik yang mempunyai kewenangan untuk itu yaitu PPAT. ${ }^{5}$ Pindahnya hak atas tanah haruslah didaftarkan, dikerjakan dimuka Pejabat Pembuat Akta Tanah yang dengan mana memiliki fungsi kekuatan untuk masing-masing para pihak baik yang menjual atau yang melepaskan hak atas tanahnya maupun pembeli yang hendak mendapatkan hak, kehadiran para pihak yang terlibat juga bisa diwakilkan dengan surat kuasa sah.

Akta jual beli yang dibuat dan ditandatangani dimuka PPATakan membuktikan dengan benar bahwa telah dilaksanakannya suatu perbuatan hukum beralihnya hak suatu tanah dengan disertakan pembayaran serta membuktikan bahwa penerima hak sudah menjadi pemilik yang baru atas tanah tersebut. ${ }^{6}$

Para pihak yang telah setuju untuk melaksanakan perikatan jual beli, kemudian menuangkan kedalam bentuk tertulis dihadapan PPAT. Perjanjian ini wajib dikerjakan berdasar pada syarat-syarat sahnya untuk membuat perjanjian yang telah ditentukan atas Pasal 1320 Kitab Undang-Undang Hukum Perdata (selanjutnya disebut KUHPer) didalam ketentuan yaitu terdapat empat syarat didalamnya harus dipenuhi jika para pihak ingin melaksanakan perikatan.

Persetujuan atau konsensus yang dimana para pihak mencapai kata sepakat atas sesuatu diperjanjikan, syarat yang kedua yaitu cakap, orang yang akan melakukan perjanjian harus cakap berarti sudah dewasa dan sehat akal pikirnya, syarat ketiga yaitu suatu hal tertentu dimana didalam perikatan tersebut harus jelas benda atau barang yang akan diperjual belikan, dan syarat yang keempat yaitu sebab yang halal yang dimana didalam perjanjian tersebut tidak memuat suatu sebab yang dilarang.

Perjanjian ini dibuat untuk menghindari sengketa dikemudian hari, maka akan lebih pasti dan lebih kuat apabila perjanjian tersebut apabila dibuat oleh notaris. Karena menurut R. Soegondo Noto Disoerjo, profesi notaris yaitu seorang pejabat publik yang memiliki wewenang dan tugas untuk mengeluarkan akta notarial atau otentik. Syarat wajib dipenuhi dalam perjanjian jual beli yaitu syarat terang dan tunai yang dilaksanakan dan dilakukan dimuka PPAT supaya pembuktian perjanjian jual beli tersebut lebih kuat karena sudah dibuat dihadapan seorang notaris sesuai tercantum pada peraturan Perundang-Undangan yang telah diatur pada Pasal 37 ayat (1) tentang pendaftaran tanah yang pada intinya merumuskan tentang peralihan tanah dengan cara jual beli, hibah, tukar menukar, maupun peristiwa hukum. Pemindahan tersebut hanya dapat dipastikan keasliannya dengan sertifikat yang dikeluarkan oleh PPAT, sebagai pejabat yang mempunyai kuasa dalam merancang akta autentik. ${ }^{7}$

\footnotetext{
${ }^{5}$ Firdaus, R., Rahmawati, D., Kastalany, K., Ridodi, M. A., Gunawan, A., Septiawan, A.A\& Habibie, R. (2017). Perlindungan Hukum Bagi Pembeli Dalam Perjanjian Pengikatan Jual Beli Tanah Yang Masih Berstatus Hak Pengelolaan. Lambung Mangkurat Law Journal, 2(1), 112-122, h.2

${ }^{6}$ SN, Herlina Ratna. (2015). Kewenangan Pejabat Pembuat Akta Tanah Dalam Perjanjian Jual Beli

Tanah. Keadilan Progresif, 6(2), h.96

${ }^{7}$ Santoso, S. D. (2018). Kekuatan Hukum Akta Jual Beli Tanahyang Dibuat PPAT (Studi Kasus Putusan Kasasi MA No. 787 K/Pdt/2013). Al-Qanun: Jurnal Pemikiran dan Pembaharuan Hukum Islam, 21 (1), 169-191. h. 6
} 
Peristiwa hukum jual beli hak atas tanah, pihak penjual maupun penawar haruslah memenuhi berkas persyaratan jual beli tanah, telah sepakat dan dilakukan, disetujui di hadapan Pejabat PPAT dan dihadirkan 2 orang untuk menjadi saksi yang telah memenuhi kriteria sebagai alat bantu bukti apabila dimasa yang akan datang terjadi sengketa. Sertifikat yang dirancang oleh PPAT adalah akta yang memiliki kekuatan sempurna apabila sertifikat dijadikan alat bukti. ${ }^{8}$ Setelah selesai dibuat akta peralihan hak atas tanah tersebut, maka PPAT akan mendaftarkan akta tersebut ke kantor Pertanahan terdekat dengan tujuan orang akan mengetahui bahwa tanah yang telah didaftarkan tersebut telah berpindah tangan, dengan dikeluarkannya sertifikat yang baru dapat bertujuan untuk membuktikan bahwa tanah tersebut telah berpindah tangan ke pemilik yang baru. ${ }^{9}$

Didalam studi kasus Putusan Peninjauan Kembali Mahkamah Agung No.337 PK/Pdt/2015 telah terjadi pembatalan akta jual beli yang dimana permasalahan berawal terjadi dari adanya gugatan dari ibu tiri penjual yang merasa tidak mendapat bagian dari hasil penjualan tanah peninggalan almahrum suaminya, lalu terjadilah gugat menggugat antara ibu tiri penjual dan penjual tanah tersebut. Penjual merasa berhak untuk menjual harta warisan peninggalan almahrum ayahnya yang telah meninggal karena merupakan satu-satunya anak laki-laki yang dimana didalam hukum Adat di Bali yang secara turun temurun menjalankan sistem kekeluargaan patrilineal, kekuasaan ada pada keturunan anak laki-laki. Sedangkan setelah almahrum ayah penjual tersebut meninggal, ibu tirinya tersebut meninggalkan rumah dan memilih tinggal dengan anak kandungnya dari suami sebelumnya. Ibu tirinya tersebut datang kembali dan menggugat setelah mengetahui anak tirinya tersebut telah menjual tanah peninggalan almahrum suaminya tersebut. Berdasar pada Putusan Peninjauan Kembali Mahkamah Agung No.337 PK/Pdt/2015 yang menyatakan bahwa ibu tiri dari penjual berhak atas tanah peninggalan almahrum suaminya tersebut. Berdasarkan putusan tersebut akta jual beli hak atas tanah yang dirancang antara I Gusti Alit Pudja dengan pembelinya Khow Tjaw Tiam dibatalkan. I Gusti Alit Pudja harus menggembalikan uang yang diberikan oleh Khow Tjaw Tiam untuk membayarkan tanahnya tersebut senilai Rp. 385.000.000,- sedangkan Khow Tjaw Tiam harus mengembalikan tanah beserta bangunan tersebut kepada I Gusti Alit Pudja.

Pihak pembeli yaitu Khow Tjaw Tiam merasa dirugikan karena ia harus mengembalikan tanah yang telah ia beli pada tahun 1992. Pada tahun tersebut harga tanah yang berada di Jalan W.R Supratman, Kesiman memang berkisaran harganya Rp. 385.000.000,-. Tetapi pada tahun ini harga tanah di wilayah W.R Supratman, Kesiman sudah mulai meningkat. Khow Tjaw Tiam hanya menerima uang Rp. 385.000.000, beserta bunganya. Jadi total yang ia dapatkan hanya Rp. 1.400.000.000, pihak Khow Tjaw Tiam merasa sangat dirugikan karena menurut nilai jual objek pajak harga tanah di Jalan Raya W.R Supratman Kesiman berkisar seharga Rp. 1.000.000.000 Per meter pesegi. Berdasarkan pemaparan di atas, penting dilakukannya penelitian mengenai: Bagaimanakah faktor-faktor yang dapat menjadi pengaruh dibatalkannya

\footnotetext{
${ }^{8}$ Indri Hadis is wati. (2014). Kepastian Hukum dan perlindungan Hukum Hak Atas Tanah. Ahkam, Volume 2. Nomor 1. H. 121

${ }^{9}$ Permadi, I. (2016). Perlindungan Hukum terhadap Pembeli Tanah Bersertifikat Ganda Dengan cara ItikadBaik Demi Kepastian Hukum. Yus tis ia Jurnal Hukum5(2), 448-467, h.1
} 
akta jual beli hak atas tanah? dan bagaimanakah Perlindungan hukum bagi pihak pembeli akibat dibatalkannya akta jual beli?

\section{Metode Penelitian}

Menurut Morris L. Cohen dan Kent C. Olson didalam bukunya yang berjudul Legal Research yang menyatakan bahwa penelitian hukum berdasar pada kaidah perundangundangan untuk menjalankan atau menerapkannya prakteknya didalam masyarakat. Tipe penelitian yang saya gunakan yaitu penelitian hukum empiris. Di dalam penelitian empiris hukum memegang konsep sebagai sesuatu yang dapat diamati didalam kehidupan nyata. Cara penelitiannya yaitu dengan awal penelitian meneliti data sekunder setelahnya lalu saya lanjutkan dengan menelaah data primer yang ada dilapangan. Data sekunder didapat melalui wawancara yang dilakukan secara langsung, sedangkan data primer saya dapat dari Kitab Undang-Undang Hukum Perdata, Undang-Undang Nomor 5 Tahun 1960 tentang Peraturan Dasar Pokok-Pokok Agraria. Setelah data telah terkumpul maka saya akan menganalisis secara deskriptifkualitatif yang kemudian menjadi konklusi.

\section{Hasil Dan Pembahasan}

\subsection{Faktor-Faktor yang dapat menjadi pengaruh dibatalkannya akta jual beli hak atas tanah}

Pertumbuhan ekonomi selalu berkembang dan menjadikan tanah menjadi berharga dan memiliki harga investasi yang tinggi. Untuk memenuhi kebutuhan hidup, kegiatan jual beli biasa dilakukan masyarakat. Apabila kedua pihak ingin melaksanakan kegiatan jual beli maka kedua belah pihak haruslah memenuhi syaratsyarat apabila ingin membuat suatu kesepakatan yang sebagaimana tercantum didalam Kitab Undang-Undang Hukum Perdata Pasal 1320 yang pada intinya menentukan:

1. Kesepakatan bagi mereka yang akan melaksanakan perikatan, yang memiliki makna apabila para pihak penjual maupun pembeli ingin melaksanakan perbuatan hukum jual beli maka harus saling sepakat dan menyetujui kesepakatan yang telah disetujui dengan itikad baik.

2. Cakap adalah slah satu syarat wajib bagi pihak yang akan melaksanakan suatu perbuatan hukum yaitu sudah mencapai cukup umur, dalam keadaan yang sehat secara fisik dan fikiran, tidak dilarang oleh suatu aturan dalam menjalankan suatu perbuatan.

3. Suatu hal tertentu yaitu objek ditentukan dalam suatu kontrak harus nyata dan konkrit yaitu ditentukam jenis maupun jumlahnya.

4. Suatu sebab yang halal yaitu causa atau substansi perjanjian tersebut tidaklah berlawanan dengan aturan dan perundang-undangan.

Keempat syarat pokok tersebut wajib dipenuhi oleh kedua pihak baik pembeli maupun penjual, karena jikalau ada satupun syarat yang tidak sesuai atau dipenuhi maka dapat menjadikan perjanjian tersebut cacat serta dapat diancam batal. Apabila syarat subjektif yaitu syarat 1 dan 2 tidak terpenuhi yang mana berarti syarat mengenai para pihak maka perjanjian tersebut dapat dibatalkan, tetapi jika syarat 
objektifnya yang mana berarti dasar mengenai objek yang akan diperjanjikan tidak terpenuhi maka perikatan itu dapat batal demi hukum.

Pembatalan ialah dinyatakannya batal suatu tindakan hukum karena adanya tuntutan oleh pihak yang dibenarkan untuk menuntut pembatalan akta tersebut. Apabila suatu akta tidak memenuhi syarat sahnya perjanjian yang telah ditentukan oleh UndangUndang yang tidak terpenuhinya syarat subjektif maupun syarat objektif, maka dengan dasar pertimbangan Hakim Pengadilan Negeri dapat membatalkan suatu akta PPAT dalam bentuk batal demi hukum apabila tidak memenuhi syarat subjektif maupun syarat objektif. Maka dengan ini, harus diterapkannya perlindungan hukum dalam masyarakat supaya melindungi masyarakat yang dari perbuatan semena-mena yang tidak sesuai dengan aturan hukum sehingga mewujudkan masyarakat yang damai dan tertib.

Berdasarkan kepada analisis kasus Putusan Peninjauan Kembali Mahkamah Agung No. 337 PK/Pdt/2015 yaitu tanah peninggalan almahrum I Gusti Ngurah Mantra yang telah dijual oleh anak kandungnya yaitu I Gusti Alit Puja dan dituntut oleh ibu tiri atau istri kedua ayahnya yang merasa dirugikan karena tidak mendapatkan bagian dari hasil penjualan tanah tersebut, maka berdasarkan putusan jual beli tersebut cacat hukum. Akibat dari pembatalan akta tersebut maka menumbulkan kerugian bagi pihak pembeli dari tanah tersebut karena pembeli harus mengembalikan tanah yang telah ia beli. ${ }^{10}$

Jual beli hak atas tanah harusla dibuat dan disetujui dimuka Pejabat yang berwenang, yang telah ditetapkan di ketentuan Pasal 37 Peraturan Pemerintah Nomor 24 Tahun 1997 tentang pendaftaran tanah yang didalamnya pada intinya menjelaskan perbuatan hukum yaitu pemindahan hak milik melalui upaya jual beli yang hanya dapat terdaftar apabila dapat ditunjukkan dengan persetujuan dari PPAT.

Berdasarkan wawancara dengan notaris ibu Margawati, bahwa menurut KUHPerdata didalam hukum perjanjian Indonesia ada beberapa sebab yang dapat membatalkan perjanjian yaitu:

1. Salah satu syarat sahnya perjanjian tidak dapat dipenuhi lalu kemudian dapat menyebabkan kesepakatan yang telah dikerjakan dapat batal demi hokum dan dapat dibatalkan.

2. Tidak dipenuhinya ketentuan yang telah ditetapkan oleh Undang-Undang untuk perikatan yang bersifat formil berdampak pada perjanjian yang telah dibuat tersebut menjadi batal demi hukum

3. Terpenuhinya ketentuan batal.

4. Pembatalan yang dilakukan oleh pihak ketiga.

5. Pencabutan yang dilakukan oleh pihak yang mempunyai kewenangan khusus yang berdasar kepada Undang-Undang.

Seperti studi kasus yang dibahas dalam jurnal ini ialah, akta jual beli ha katas tanah yang telah disepakati dihadapan PPAT yaitu kontrak perjanjian yang substansinya

\footnotetext{
${ }^{10}$ Sunanda, B., Wahab, A. A.,\& Abubakar, M. (2013). Pembatalan Perjanjian Jual Beli Tanah Meskipun Telah memiliki Akta Jual Beli Tanah Dari PPAT Oleh Pengadilan Negeri. Jurnal Ilmu Hukum ISSN, 2302, 0180. h.5
} 
batal demi hukum menurut putusan pengadilan yang dimaksudkan perjanjian yang batal demi hukum yaitu perjanjian yang sudah dikerjakan dianggap tidak pernah ada karena tidak terpenuhinya salah satu unsur ada dengan demikian dianggap tidak pernah adanya suatu janji diantara pejual maupun pembeli, sedangkan perjanjian yang dapat dibatalkan yaitu perjanjian dan perikatan yang sudah dibuat tersebut tidak memenhi unsur subyektif sesuai dengan yang diatur pada Pasal 1320 KUHPerdata.

Kepastian hukum merupakan jaminan yang diberikan oleh Pemerintah dengan mengadakan pendaftaran tanah yang berdasarkan kepada kaidah-kaidah yang telah diatur didalam peraturan perundang-undangan. Rechts cadaster atau legal cadaster adalah istilah dari pendaftaran tanah yang memiliki tujuan jaminan yang meliputi batas, letak, luas, maupun status tanah dan siapa saja yang mempunyai hak tersebut. Dalam recht cadaster juga mencakup kepastian hukum dari status hak orang yang terdaftar, kepastian objek, dan kepastian subjek. Sedangkan fiscal cadaster yaitu pendaftaran tanah yang memilki tujuan hendak memastikan siapa-siapa saja berhak untuk menjalankan kewajiban atas tanahnya tersebut.

\subsection{Perlindungan Hukum Bagi Pihak Pembeli Akibat Dibatalkannya Akta Jual Beli.}

Negara Indonesia adalah Negara Hukum maka harus mendukung pemberian perlindungan dan jaminan kepada seluruh masyarakat untuk mendapatkan hak yang sama kepada setiap orang, karena Negara Hukum terlahir dari perjuangan individu yang ingin melepaskan dirinya dari kesewenang-wenangan. Dalam Negara Hukum setiap orang berhak untuk mendapatkan kesamaan (equality) dan ada pula pembatasan (restriction), sarana yang membatasi kedua hal tersebut adalah hukum.

Pengertian perlindungan hukum menurut Soetjipto Rahardi yang menyatakan bahwa untuk memberi perlindungan kepada kepentingan seseorang dapat denan cara memberikan kewenangan kepadanya untuk mengambil tindakan atas kepentingannya tersebut. Dapat dikatakan maka tujuan utama daripada hukum adalah memberikan perlindungan kepada rakyat luas. Karenanya, perlindungan hukum yang ditujukan kepada rakyat hendaknya direalisasikan dalam bentuk kepastian hukum. Perlindungan hukum dalam arti luas yaitu perlindungan hukum yang tidak hanya diberikan kepada seluruh makhluk hidup dan segala yang diciptakan oleh Tuhan yang dapat dimanfaatkan untuk kehidupan yang adil dan damai11, Sedangkan menurut Setiono perlindungan hukum yaitu tindakan yang bertujuan untuk melindungi dan menjaga masyarakat dari perilaku semena-mena, penguasa yang melanggar untuk mewujudkan ketertiban dan ketentraman didalam masyarakat.

Perlindungan hukum bisa dibagi terdiri dari dua jenis meliputi perlindungan hukum preventif dan perlindungan hukum represif. Adapun penjelasannya sebagai berikut: 1. Perlindungan Hukum Bersifat Preventif.

Perlindungan hukum ini memiliki maksud untuk menghindari perbuatan sebelum adanya suatu pelanggaran, perlindungan ini dibuat oleh pemerintah untuk semua masyarakat. Perlindungan ini diatur didalam peraturan perundang-undangan

\footnotetext{
${ }^{11}$ Muljono, B.E. (2016). Perlindungan Hukum Bagi Pihak Penjual Terhadap Pihak Pembeli Wanprestasi Dalam Ikatan Jual Beli Tanah. Jurnal Independent, 4(2), 4 1-146, h. 42
} 
guna mencegah adanya kemungkinan pelanggaran-pelanggaran hukum, maka didalam aturan tersebut diatur batasan-batasan didalam menjalankan kewajiban.

2. Perlindungan Hukum Bersifat Represif.

Perlindungan hokum bersifat represif ialah hukuman tambahan yang dapat dijatuhkan apabila kemudian terjadi sengketa akibat adanya wanprestasi. Perlindungan ini dapat meliputi sanksi denda, penjara, serta hukuman tambahan.

Setiap masyarakat berhak untuk mendapatkan perlindungan hukum, karena didalam Pancasila dan dasar Negara Hukum adalah sumber dari perlindungan hukum itu karena didalamnya telah diatur perlindungan terhadap harkat dan martabat serta prinsip pengakuan. Seperti didalam studi kasus Putusan Peninjauan Kembali Mahkamah Agung No. 337 PK/Pdt/2015 yang dimana berdasarkan tuntutan dari pihak ketiga yang membuat pengadilan memutuskan bahwa perjanjian jual beli ha katas tanah tersebut dibatalkan, maka pihak penjual membayarkan kembali sebesar yang sudah dibayarkan oleh pihak pembeli sebesar Rp. 385.000.000,- beserta bunganya selama $6 \%$ pertahun jadi jumlah yang harus dikembalikan oleh penjual yaitu Rp. 1.400.000.000,-sedangkan dari pihak pembeli harus mengembalikan tanah yang sudah dibelinya.

Perlindungan hukum yang kemudian dapat diberikan kepada pihak pembeli yaitu, pembeli pasti sangat merasa dirugikan, karena ia membeli tanah tersebut pada tahun 1992 yang dimana pada tahun tersebut harga tanah seluas 28 meter persegi sejumlah Rp. 385.000.000, tetapi jika dilihat pada tahun sekarang harga tanah NJOP yang berlokasi di Jalan WR Supratman berikisar antara harga Rp. 1.000.000.000,- per meter persegi. Maka pihak pembeli merasa sangat dirugikan apabila uang yang diganti dengan sejumlah uang yang telah ditetapkan oleh pengadilan maka seharusnya perlu ada pertimbangan lagi supaya tidak ada kesalahpahaman yang berujung kerugian oleh salah satu pihak.

\section{Kesimpulan}

Perjanjian haruslah berdasar kepada Pasal 1320 yaitu syarat sahnya suatu perikatan. Apabila tidak dipenuhinya salah satu dari keempat syarat yang sudah ditetapkan Undang-Undang, maka perikatan tersebut dapat batal demi hukum. Setelah memenuhi syarat sahnya perjanjian maka kedua belah pihak dapat meleges perjanjian tersebut kepada pejabat yang memiliki wewenang untuk itu yaitu PPAT supaya setelah akta jual beli tersebut sudah disetujui, maka akan didaftarkan oleh PPAT dan perlindungan hukum kepada pihak pembeli dalam studi kasus ini haruslah dipertimbangkan untuk mendapatkan keadilan, karena dilihat dari putusan Pengadilan bagian ganti rugi yang didapat oleh pembeli tidaklah adil karena pengadilan masih mengacu pada harga tanah pada tahun 1992 tepat pada tahun transaksi jual beli tersebut dilaksanakan, padahal jika dilihat pada tahun ini NJOP harga tanah di kawasan Jalan WR Supratman sudah melambung tinggi maka pihak pembeli merasa sangat dirugikan dengan jumlah uang ganti rugi yang ditetapkan. 


\section{Daftar Pustaka / Daftar Referensi}

\section{$\underline{\text { Buku }}$}

Achmad Rubaie. (2007). Hukum Pengadaan Tanah Untuk Kepentingan Umum. Malang. Bayumedia

Adrian Sutedi. (2009). Peralihan Hak Atas Tanah dan Pendaftrannya. Jakarta. Sinar Grafika

\section{Jurnal}

Dananjaya, N. S.(2016). Pembatalan Sertipikat Hak Milik Dan Akibat Hukumnya Terhadap Akta Jual Beli. Jurnal Bina Mulia Hukum. Volume 1, Nomer 1.

Firdaus, R., Rahmawati, D., Kastalany, K., Ridodi, M. A., Gunawan, A., Septiawan, A.A\& Habibie, R. (2017). Perlindungan Hukum Bagi Pembeli Dalam Perjanjian Pengikatan Jual Beli Tanah Yang Masih Berstatus Hak Pengelolaan. Lambung Mangkurat Law Journal, 2(1), 112-122.

Indri Hadisiswati. (2014). Kepastian Hukum dan perlindungan Hukum Hak Atas Tanah. Ahkam, Volume 2. Nomor 1.

Muljono, B. E. (2016). Perlindungan Hukum Bagi Pihak Penjual Terhadap Pihak Pembeli Wanprestasi Dalam Ikatan Jual Beli Tanah. Jurnal Independent, 4(2), 4 1-46.

Permadi, I. (2016). Perlindungan Hukum terhadap Pembeli Tanah Bersertifikat Ganda Dengan cara Itikad Baik Demi Kepastian Hukum. Yustisia Jurnal Hukum 5(2), 448-467.

SN, Herlina Ratna. (2015). Kewenangan Pejabat Pembuat Akta Tanah Dalam Perjanjian Jual Beli Tanah. Keadilan Progresif, 6(2).

Sunanda, B., Wahab, A. A.,\& Abubakar, M. (2013). Pembatalan Perjanjian Jual Beli Tanah Meskipun Telah memiliki Akta Jual Beli Tanah Dari PPAT Oleh Pengadilan Negeri. Jurnal Ilmu Hukum ISSN, 2302, 0180.

Santoso, S. D. (2018). Kekuatan Hukum Akta Jual Beli Tanah yang Dibuat PPAT (Studi Kasus Putusan Kasasi MA No. 787 K/Pdt/2013). Al-Qanun: Jurnal Pemikiran dan Pembaharuan Hukum Islam, 21 (1), 169-191.

\section{Peraturan Perundang-Undangan}

Kitab Undang-Undang Hukum Perdata (Burgerlijk Wetboek)

Undang-Undang Nomor 5 Tahun 1960 Tentang Peraturan Dasar Pokok-Pokok Agraria Undang-Undang Nomor 2 Tahun 2014 Tentang Perubahan Atas Undang-Undang Nomor 30 Tahun 2004 Tentang Jabatan Notaris 